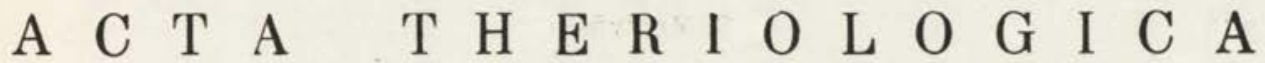

VOL. XVI, 23: $371-386$.

BIAŁOWIEŻA

November, 1971

\author{
Stefan M Ę C Z Y N S K I
}

\section{Morphohistological Analysis of the Male Genital Organs of the Genus Citellus}

[With 6 Figs \& Plates I-III]

\begin{abstract}
A description is given of the structure of the male genital organs in adult individuals of Citellus suslicus and $C$. citellus during the rut. A detailed analysis is given of the terminal parts of the ducts of the sex glands in colliculus seminalis and the way in which they open into canalis urogenitalis. Distinct differences were found in the arrangement of these ducts in the two species examined. The presence of uterus masculinus was shown in C. suslicus. Examination was made of the structure of pars pelvina urethrae and detailed analysis of gl. genitales accessoria. Gl. bulbi and ductus penis were found to be present. In both the species examined this gland has two chambers and identical histological structure. Differences were shown in the structure of os glandis in the two species of Citellus. Similarities in the structure of the genital organs in Citellus and other representatives of Sciuridae are discussed.
\end{abstract}

\section{INTRODUCTION}

Morpho-histological studies of the genital organs are of considerable importance in establishing the phylogenesis of species, as the complex of genital organs is one of the most stable taxonomic criteria, hence the comparative character of the majority of such studies. The male genital organs of the Sciuridae family have been described for several species of squirrels, dormice and marmots (Krölling, 1921; Mossma n, Lawlah \& Bradley, 1932; Prasad, 1956; Kratochvil, 1964). The genital organs have also been described for Aplondontia rufa R afinesque, a species related to the Sciuridae family (Pfeiffer, 1956).

No exhaustive elaborations of the genital organs of C. suslicus and C. citellus have been found in available literature. O u d e m a n s (1892) cited after Mossman et al., 1932, gave only a small amount of information on the genital organs in Spermophilus citellus, and M e is e n h e i$\mathrm{m}$ e $\mathrm{r}$ (1930) gave only a brief description and diagram of glans penis 
and os penis in Spermophilus. The figure was taken from the study by Gilbert (1892). Among more recent publications the study by $\mathrm{Re}$ šetnik \& Balahnin (1967), concerned with the taxonomy of three species of the genus Citellus, contains drawings of os glandis of C. suslicus and C. citellus. A short note on the structure of glans penis in these species is also to be found in the publication by Ot tow (1955). All the data on this subject are, however, fragmentary and scattered, and on this account the present study attempts to fill the gap which exists in this respect. It also forms an introduction to more comprehensive studies on the reproductive cycle in both sexes of Citellus.

\section{MATERIAL AND METHODS}

A morpho-histological analysis was made of the genital organs of 14 individuals belonging to two Polish species: Citellus suslicus (G ü eld en sta e d t, 1770) $(\mathrm{N}=9$ ) and Citellus citellus ( $\mathrm{L}$ in na e us, 1766) $(\mathrm{N}=5$ ). The material was collected during the period from 1968-1970 at Gliniska in the Lublin voivodship (C. suslicus) and at Kamien Sląski, in the Opole voivodship (C. citellus). Only sexually mature males were examined.

The whole of the isolated genital organs were fixed for histological examination in Bouin's fluid, and different parts of the organs embedded in paraffin, sectioned to $5-10 \mu$ and stained with Mayer's haematoxylin and eosine water solution.

For morphological studies the genital organs were fixed in $10 \%$ formalin together with the excised pelvic part. Despite a certain degree of difficulty encountered later in preparing the organs this method is to be recommended, as the organs fully retained their shape and position. Preparations from os glandis were made by the method given by $\mathrm{L}$ a y $\mathrm{ne}$ (1954).

Macroscopic measurements of the organs were made with a slide-rule with accuracy to $0.5 \mathrm{~mm}$. As, however, the material was measured after fixing these values are approximate only.

On account of the great similarity in the anatomical structure of the genital organs in the species examined the description is based on C. suslicus, and only in cases in which considerable differences occurred detailed descriptions of some of the elements of the genital organs in C. citellus are given.

Wherever possible the anatomical nomenclature given in Nomina anatomica veterinaria (Paris, 1967) has been used.

\section{ANALYSIS OF MATERIAL}

Testes

During the rut the testes in males are $15 \mathrm{~mm}$ long, $9 \mathrm{~mm}$ wide and $7 \mathrm{~mm}$ thick (average values). Tunica albuginea of the testes is thin, transparent and reveals the very characteristic network of blood vessels. On margo liber of the testes they run parallel in the sagittal line and are similar in appearance to longitudinal bands. 
Ductuli efferentes testis (Photo 1, det) open near extremitas capitata testis, by margo epididymalis. They form a characteristic thickening, which is connected with the middle part of caput epididymidis. Microscopic cross sections of this structure reveal 7-11 ductuli efferentes testis running spirally. They are surrounded by connective tissue. Ductus deferens has no ampulla ductus deferentis.

\section{Urethra masculina}

The urethra is devided into two parts: pars pelvina urethrae and pars spongiosa urethrae, lying outside the pelvis. The boundary between these parts is formed by isthmus urethrae. In the pelvic part of the urethra two parts can be distinguished: the proximal (pars prostatica), surrounded on the dorsal side by the prostate and the distal (pars membranacea).

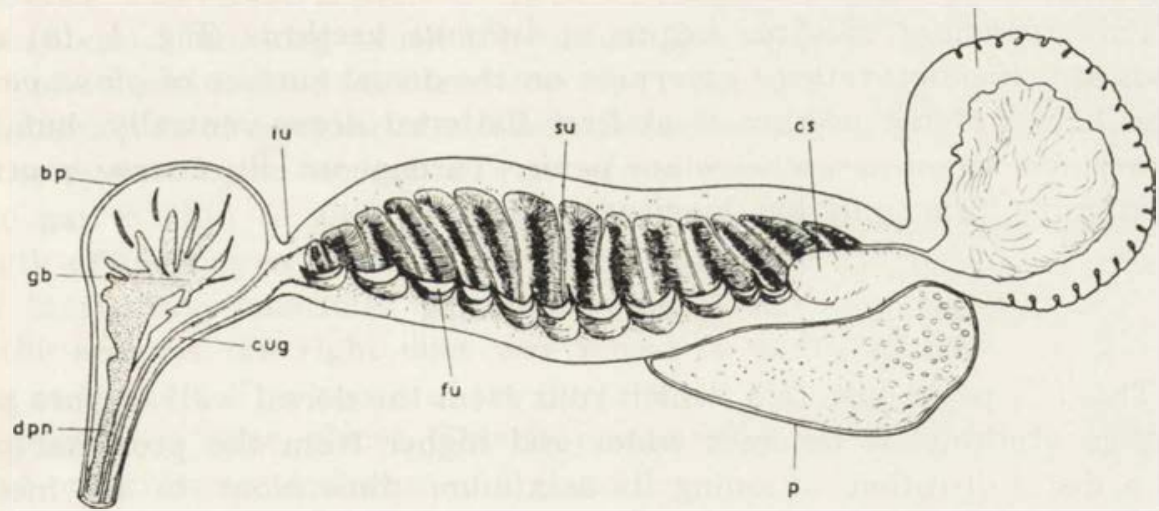

Fig. 1. C. suslicus. Longitudinal section through pars pelvina urethrae and bulbus penis.

bp - bulbus penis, cug - canalis urogenitalis, cs - colliculus seminalis, dpn ductus penis, fu - frenulum urethrae, gb - glandula bulbi, iu - isthmus urethrae, $\mathrm{p}$ - prostata, su - septum urethrae, vu - vesica urinaria.

Pars pelvina urethrae (Fig. 1) is about $14 \mathrm{~mm}$ long. It is approx. 3.5 $\mathrm{mm}$ wide in the place where it joins collum vesicae urinariae and near isthmus urethrae. It is widest on the boundary between pars prostatica and pars membranacea $-4.8 \mathrm{~mm}$; height $4 \mathrm{~mm}$.

The walls of the pelvic part of the urethra are formed of transversely striated muscles running spirally. This type of muscle is absent only on the dorsal side of the urethra adjoining the prostate, where there is 
a layer of smooth muscles and connective tissue. The lumen of the urethra is lined with mucous membrane covered by stratified epithelium, which forms numerous folds in the form of septa urethrae (Fig. 1, $\mathrm{su})$. These septa run from the lateral walls of the urethra and are arranged transversely throughout its length. On each side there is a row of $13-14$ septs, which divide the lumen of the urethra into 26 chambers. These rows are so situated in relation to each other that the septa of the left wall of the urethra are opposed to the chambers of the right wall, and vice versa. Distance between septa is about $1 \mathrm{~mm}$. The septa located between colliculus seminalis and isthmus urethrae are connected on the dorsal wall of the urethra with frenulum urethrae which runs in the sagital line (Fig. 1, fu).

In sexually active males pars pelvina urethrae is filled with secretion from the genital glands. The secretion hardens considerably when fixed. It cannot be isolated until the urethra is sectioned longitudinally. After removal it forms a good cast of the interior of the urethra.

Pars spongiosa urethrae begins at isthmus urethrae (Fig. 1, iu) and ends at orificium urethrae externum on the dorsal surface of glans penis. The lumen of the urethra is at first flattened dorso-ventrally, but becomes oval when it reaches glans penis. Throughout its course mucous membrane forms only low longitudinal folds.

\section{Colliculus seminalis}

This is a prominent fold, which runs from the dorsal wall of pars prostatica urethrae. It becomes wider and higher from the proximal part in a distal direction, attaining its maximum dimensions in its medial part, then gradually narrows and descends, passing into crista urethralis, and this in turn into frenulum urethrae.

In sexually active males of $C$. suslicus colliculus seminalis has the following dimensions: lenght $-2 \mathrm{~mm}$, height $-1 \mathrm{~mm}$ (on the basis of macroscopic measurements made of two individuals).

Three pairs of the following ducts enter colliculus seminalis (Photo 2, 3): ductus deferentes, ductus excretorii and ductus prostatici. Ductus deferentes are situated in the central part of colliculus, ductus excretorii laterally from them and ductus prostaticii occupy the most extreme positions. In the initial phase all the ducts run in one row (Photo 2), then ductus excretorii and ductus prostatici run below the apical part of colliculus. In C. suslicus, in the distal part of colliculus, ductus excretorii join ductus deferentes in a common duct (Photo $3 \mathrm{a}$ ), which ductus prostatici enter later (Photo $3 \mathrm{~b}$ ). This in turn forms ductus ejaculatorii, 
which open into canalis urogenitalis by two orifices in the lateral walls of colliculus. In some individuals ductus excretorius first connected with ductus prostaticus and only then does the common canal of these two ducts enter ductus deferens. In every case, however, there is connection of all three ducts before they open into canalis urogenitalis. Ductus ejaculatorii may also join the lumen of uterus masculinus before opening into this canal. As a result a wide canal is formed in the shape of a gap situated transversely, which joins canalis urogenitalis.

In C. citellus, as in C. suslicus, three pairs of ducts arranged similarly (Photo 9, 10) enter colliculus. Not all three are, however, connected there, the only ones to connect being ductus deferentes and ductus excretorii, whereas ductus prostatici open with a separate pair of orifices on the apex of colliculus seminalis.

\section{Uterus masculinus (Müllerian ducts)}

Uterus masculinus (Photo 2-4) in C. suslicus takes the form of two ducts about $3 \mathrm{~mm}$ long which are connected with each other in the distal part of colliculus seminalis into one short common canal, with its blind termination in the region of collum vesicae urinariae. The common part of the ducts (vagina masculina) runs along the middle part of colliculus, then passes into a wide gap and opens into canalis urogenitalis. The length of the paired ducts of uterus masculinus is not usually identical, and there may sometimes be considerable differences in length. In one of the animals the right duct was found to be approximately half as long as the left. The lumen of the ducts is very irregular and completely disappears in some places. This is connected with the fact that short blind branchings and sinuses of a glandular character run from the main ducts. The pseudostratified columnar epithelium with large nuclei (Photo 4). As the lumen is irregular it is very difficult to measure its diameter, but in any case this dimension increases from the terminal parts of the ducts to their opening on colliculus seminalis.

\section{Glandula bulbi and ductus penis}

Glandula bulbi (Photo 1,5) is the enlargement of the ducts of Cowper's glands into bulbus penis. This dilation is divided into two chambers in its initial part by septum sagittale bulbi. This septum is very thin, formed of connective tissue and smooth muscle fibres, and runs dorso-ventrally. The mucous membrane forms numerous branching folds running longitudinally and opening from the walls of the chambers and also from septum. It is covered by high columnar epithelium with an uneven surface. The cells of the epithelium contain granular cytoplasm 
and nuclei lying at the base. The gland is surrounded, particularly from the ventral side, by a thick layer of $m$. bulbospongiosus. Septum sagittale disappears in the distal direction and a common chamber is formed from which ductus penis runs (Fig. 1, dpn). In this duct there are also folds of mucosa running longitudinally and covered with columnar epithelium. Here, however, it is lower than in the gland. Ductus penis, together with pars spongiosa urethrae, are surrounded by corpus spongiosum penis and tunica albuginea (Phot. 6). These two ducts are located in sulcus urethralis corporis cavernosi penis.

About $1.5 \mathrm{~mm}$ before flexura penis from the ventral side ductus penis connects with the lumen of pars spongiosa urethrae (Photo 7).

The dimensions of $g l$. bulbi are: width $7 \mathrm{~mm}$, length $5 \mathrm{~mm}$, height $4 \mathrm{~mm}$. Length of ductus penis $-12 \mathrm{~mm}$, diameter about $1.5 \mathrm{~mm}$ (average values).

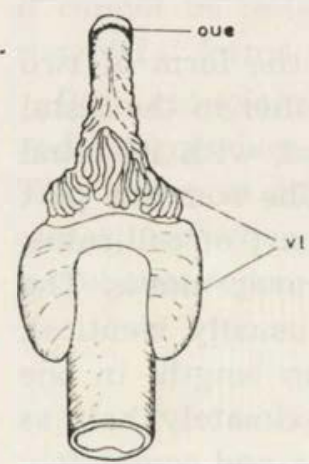

a

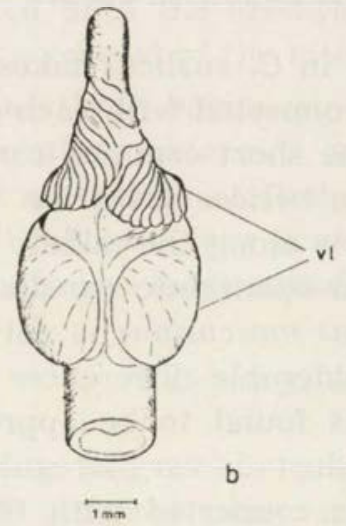

Fig. 2. C. suslicus. Glans penis. a-view from ventral side, $b$ - view from dorsal side.

oue - orificium urethrae externum, $\mathrm{vl}$ - valli laterales.
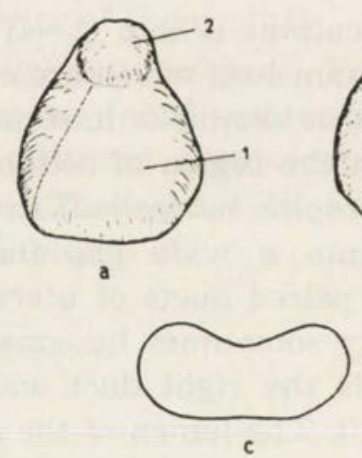

Fig. 3. C. suslicus. Prostata. a - view from dorsal side, b - view from ventral side, c - cross-section (1 - secretory part, 2 - cisternal part).

On account of the secretory character of $g l$. bulbi this gland can be considered as belonging to gl. genitales accessoriae.

The penis is formed of the following parts: pars spongiosa urethrae, bulbus penis and ductus penis (described above), and corpus cavernosum penis and glans penis.

Corpus cavernosum penis is attached by means of two crura penis to arcus pubis. These are covered by $m$. ischiocavernosus. Further along crura penis join and form one whole. Corpus cavernosum penis has on its dorsal side a deep sulcus urethralis, in which corpus spongiosum penis is located. 
The length of penis from bulbus penis to apex glandis is about $30 \mathrm{~mm}$. The penis has the characteristic flexura penis situated about $3.5 \mathrm{~mm}$ from glans penis.

Glans penis (Fig. 2a, b) has two pairs of valli laterales which are separated from each other by sulcus coronalis. The valli laterales lying proximally are larger, with weakly formed longitudinal folds, while those lying distally have well marked longitudinal folds. The apical part of glans penis is a cylindrical process about $2.5 \mathrm{~mm}$ in length and contains os glandis. The apical process on its ventral side has a transverse orificium urethrae externum. The length of the whole of glans penis is $7 \mathrm{~mm}$.
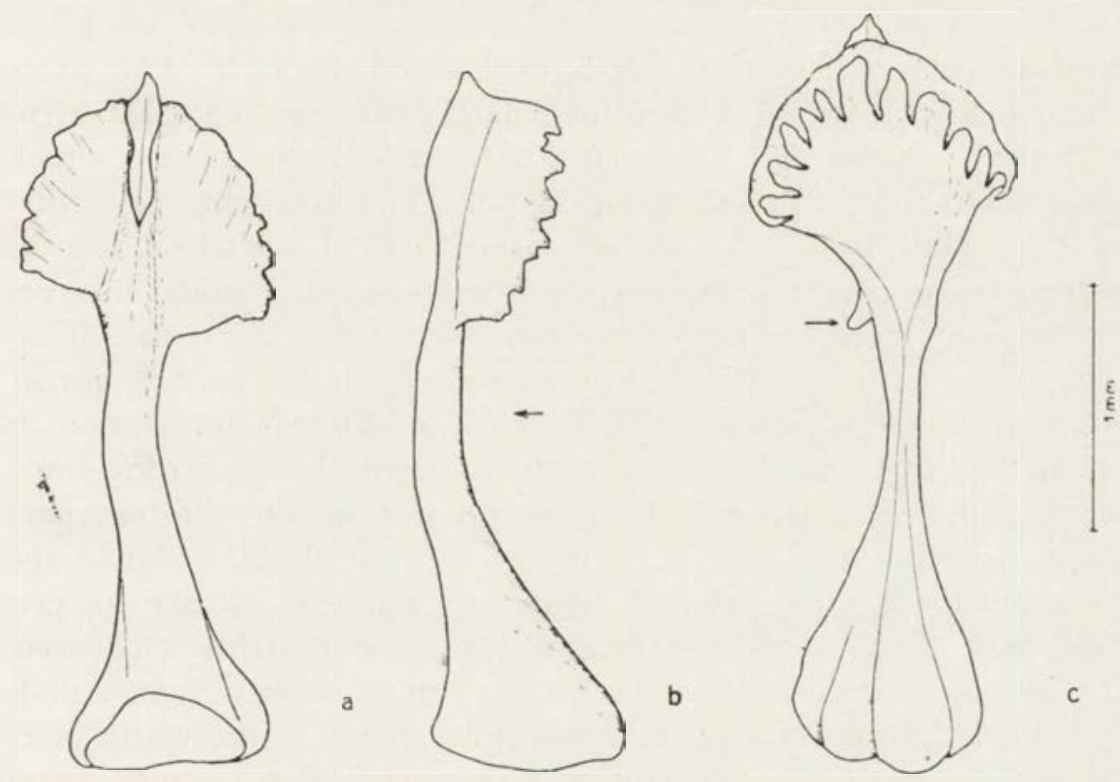

Fig. 4. Os glandis, a, b - C. suslicus: a - view from lateral side, b - view from dorsal side, $c-C$. citellus: view from ventral side.

Macroscopic examination and microscopic cross-sections through glans penis (Photo 8) did not reveal the presence of glandulae praeputiales.

Os glandis (Fig. $4 \mathrm{a}, \mathrm{b}, \mathrm{c}$ ) - three parts can be distinguished here the basal part, corpus and dilated terminal part. The basal part is thickened and united by its proximal end, in which there is a depression, with corpus cavernosum penis. This part narrows in a distal direction and passes into the middle part, which is flexed in a dorso-ventral direction. This in turn passes into a spatulate dilation, on the margins of which there are several teeth inclined in a ventral direction. On the 
dorsal side of this "spatula a crista of irregular shape runs in the sagittal line. The teeth of the "spatula " protrude on to the exterior of glans penis behind ostium urethrae externum.

In C. suslicus the measurements of os glandis are: length about $2.7 \mathrm{~mm}$, breadth of "spatula « $-1 \mathrm{~mm}$. In C. citellus - os glandis is larger, its length $3 \mathrm{~mm}$, breadth of the "spatula « $-1 \mathrm{~mm}$. The teeth on the margins of the "spatula « are longer and hamate. In addition there is a protruding tooth on the right side before the spatulate dilation. It was found in 7 out of the 10 individuals examined. A similar tooth can sometimes be found in the middle part of the "spatula" on the ventral side.

\section{Glandulae genitales accessoriae}

Prostata (Photo 1, p) is a single, oval gland, in which two parts can be distinguished (Fig. 3): a secretory part with more compact structure and smaller vesicles and a cisternal part with large vesicles which can be seen even in microscopic preparations. The secretory part, directed caudad, is wide, flattened and has a longitudinal sulcus on the ventral side for pars prostatica urethrae. The prostata surrounds the urethra with this part from the dorsal side and partly on both sides. It is connected with urethra by fairly loose connective tissue. On the dorsal side prostata adjoins the rectum, which forms an elongate impression on the gland in the form of a shallower sulcus than the preceding one. The cisternal part is situated proximally in relation to the secretory part and is distinctly separated from it. It is narrow, but slightly higher and has a round outline. Gl. vesiculares adhere to the lateral surfaces of prostata so that part of the ventral margin of the gland remains uncovered.

The average dimensions of the prostate in a sexually active male are as follows: length $8 \mathrm{~mm}$, width of secretory part $6.7 \mathrm{~mm}$, width of cisternal part $3.7 \mathrm{~mm}$, height of proximal secretory part $3.9 \mathrm{~mm}$, height of distal secretory part $3 \mathrm{~mm}$, height of cisternal part $4.2 \mathrm{~mm}$.

One pair of ducts - ductus prostatici - open on the boundary between the secretory and cisternal parts of the prostate. These ducts are very short. Microscopic cross-sections in this part of the gland reveal distinct transition of vesicular sinuses into increasingly narrow efferent ducts.

The prostate has a tubular-vesicular structure (Photo 12). The vesicles are lined with simple columnar epithelium, which is low in the vesicles of the cisternal part, and high in the vesicles of the secretory part. Characteristic drops of secretion staining dark red with eosine can be seen in the cytoplasm. The efferent ducts are lined with pseudostratified columnar epithelium. 
Gl. vesiculares (Photo 1, gv) have the form of two elongate bodies, which are so arranged that they surround the prostate from two sides and the rectum lying beneath it. The distal parts of the glands protrude beyond the posterior margin of the prostate and adhere over a small distance to $p$. membranacea urethrae. The external surface of gl. vesiculares is convex, the pericentral surface exhibiting the impressions made on it by the prostate and rectum. These impressions are clearly visible on a fixed gland. Each gland has a single ductus excretorius, very strongly coiled and united by connective tissue with the corpus of the gland and appearing to form a uniform whole with it. This duct cannot be uncoiled until the connective tissue has been removed.

The dimensions of $g l$. vesiculares in adult males during the rut are as follows: length $13 \mathrm{~mm}$, width $6 \mathrm{~mm}$, thickness $3 \mathrm{~mm}$ (average values).

Gl. vesiculares are of tubular-vesicular structure (Photo 11), which is clearly visible even in macroscopic preparations. The caniculi are lined with simple columnar epithelium with an even surface and are filled with secretion staining red with eosine. Ductus excretorii in the terminal part are lined with pseudostratified columnar epithelium and are also filled with secretion.

Gl. bulbo-urethrales (Cowperi) (Photo 1, gbu) are paired, oval glands lying on the lateral surfaces of the terminal part of the rectum, between the following muscles: $m$. ischio-cavernosus and $m$. bulbo-spongiosus. Ductus gl. bulbo-urethrales are wide (1 $\mathrm{mm}$ diameter) and coiled round the gland. They narrow in the distal parts and enter bulbus penis from the ventral side.

Dimensions of the glands are: length $5.8 \mathrm{~mm}$, width $5.5 \mathrm{~mm}$, thickness $4.5 \mathrm{~mm}$ (average values).

Gl. bulbo-urethrales are of tubular-vesicular structure and are surrounded by a layer of $m$. bulbo-spongiosi. The connective tissue penetrating into the interior of the gland divides it into lobules, and in the middle part into several cystae sinus interglandularis. Caniculi, mainly grouped on the periphery of the gland, are lined with simple columnar epithelium with an even surface. The cell nuclei lie near the basal membrane. Between the rows of cells there is a very small amount of connective tissue.

The glands and excretory ducts are filled with secretion which hardens very considerably after fixing. This secretion stains pink.

\section{DISCUSSION}

The structure of the male genital organs in Sciuridae possesses many characters typical only of this group, such as: presence of $\mathrm{gl}$. bulbi and 
ductus penis and also spiral coiling of ductus gl. bulbo-urethrales (Cowperi) and parallel arrangement of the blood vessels of the testes. The first two of the above structures have not been found in any other animals and they are considered as the most characteristic of Sciuridae (M s s m a n et al., 1932).

The genital organs in C. suslicus and C. citellus completely correspond to the general description given for Sciuridae (M os s m a n et al., 1932). It is only after detailed analysis has been made of the structure of the genital glands in Citellus that many differences can be found in comparison with such species as: Sciurus vulgaris, Marmota marmota, Raiufa indica maxima and also Citellus tridecemlineatus.

The characteristic structure of pars pelvina urethrae in C. suslicus and $C$. citellus are transverse folds in the form of septa. Similar folds, numbering 13 pairs, are observed in C. tridecemlineatus ( $\mathrm{M}$ os s man et al., 1932). All three species have tubules of frenulum urethrae on the dorsal side. Septa urethrae also occur in Tamias striatus (15 pairs), but are less strongly developed than in $C$. tridecemlineatus and frenulum urethrae does not occur (M os s m a n et al., 1932). These structures were not found in Sciurus, Marmota and Ratufa.

Gl. urethrales were not found in pars pelvina urethrae of the animals examined, neither were they found in pars spongiosa urethrae. This confirms the assumption reached by Mossman et al. (1932) that these glands are absent in Sciuridae.

The most interesting details of the structure of colliculus seminalis are: the presence or absence of utriculus prostaticus, the course taken by the terminal parts of the ducts of the genital glands, the way in which they are connected and their opening into canalis urogenitalis. The topography of these elements in various species of the Sciuridae family is illustrated in Fig. 5.

Utriculus prostaticus occurs only in C. suslicus, but no such structure was found in C. citellus. In some of the preparations only is it possible to observe, in the middle part of colliculus seminalis, near its distal end, and accumulation of cells with large nuclei. They are similar in appearance to the cells of the horns of utriculus prostaticus in C. suslicus. It was not found, however, that they surrounded any duct opening into pars prostatica urethrae. The arrangement of these cells is compact, without a lumen. It is probable that this structure is a short utriculus prostaticus similar to that described by Mossman et al. (1932) in C. tridecemlineatus.

Utriculus prostaticus also occurs in other species of the Sciuridae family. It has been given for Sciurus carolinensis, Tamias striatus, Ci- 
tellus tridecemlineatus, Tamiasciurus hudsonicus (Mossman et al., 1932), Sciurus vulgaris (K r ölling, 1921) and Funambulus palmarum (Pras ad, 195.4). It is absent in Marmota marmota ( $\mathrm{Kr}$ a toc hvil, 1964) and in Ratufa indica maxima ( $\mathrm{Pr}$ a s a d, 1954).

Of above species this structure is undoubtedly best formed in C. suslicus. It has long paired canals corresponding to the uterine horns and a common canal corresponding to the vaginal part of the Müllerian ducts, and on the strenght of these has been described as uterus masculinus. It does not, however, possess a structure like the typical uterus masculinus in Castor canadensis (cf. C on a w a y, 1958). The typically

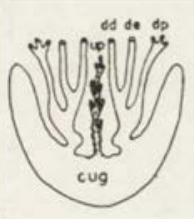

1

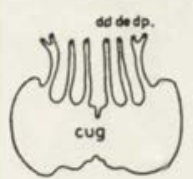

6

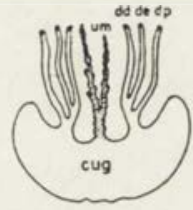

2

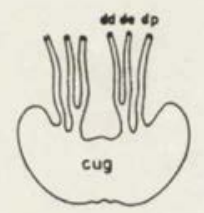

7

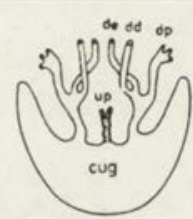

3

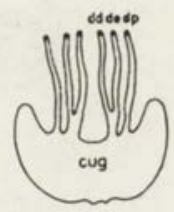

8

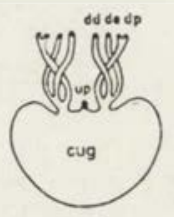

4

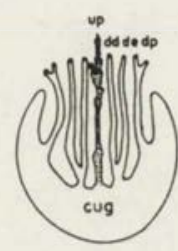

9

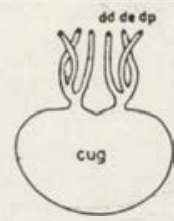

5

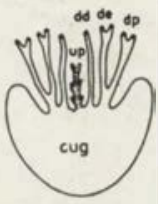

10

Fig. 5. Cross-sections through pars prostatica urethrae in region of colliculus seminalis in different species of the Sciuridae family.

cug - canalis urogenitalis, de - ductus excretorius, dd - ductus deferens, dp ductus prostaticus, um - uterus masculinus, up - utriculus prostaticus, 1 - Sciurus carolinensis and $S$. niger (M o s $\mathrm{m}$ a $\mathrm{n}$ et al., 1932), $2-$ C. suslicus (orig.), $3-$ S. vulgaris (M os s m a $\mathrm{n}$ et al., 1932), 4 - Tamias striatus (M o s sman et al., 1932), 5 - Ratufa indica maxima (P r a s a d, 1954), 6 - C. tridecemlineatus (M o s s m a n et al., 1932), $7-$ C. citellus (orig.), 8-Marmota marmota latirostris (drawing based on description: $\mathrm{Kr}$ a to $\mathrm{chvil}$, 1964), 9 - Tamiasciurus hudsonicus (M os s-

$\mathrm{man}$ et al., 1932), 10 - Funambulus palmarum palmarum ( $\mathrm{Pras}$ a d, 1954).

formed endometrium layer is absent here, the horns are not free but are surrounded, together with the terminal parts of ductus efferentes, by connective tissue and the muscle layer of pars prostatica urethrae.

In other species utriculus prostaticus is usually single, of varying length and is more or less complicated. It is only in Sciurus vulgaris that it has short, paired ducts with blind ends in the cranial direction. In C. tridecemlineatus it is very small, has no lumen and has been found in one individual only. All authors stress the glandular character of utriculus prostaticus. 

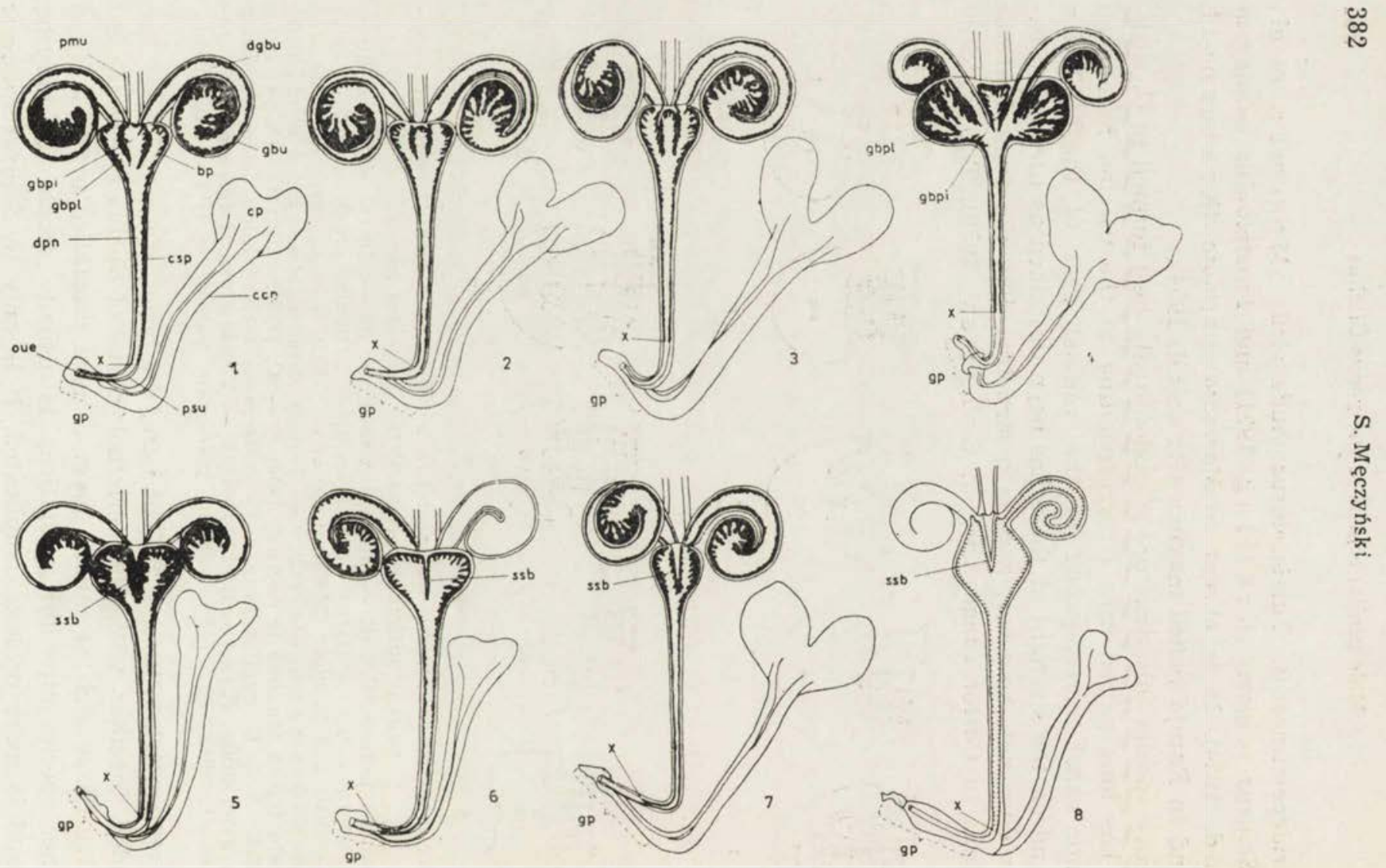

Fig. 6. Sections through glandula bulbi and ductus penis in different species of the Sciuridae family. 
The arrangement of the terminal parts of the excretory ducts of the genital glands and their opening on colliculus seminalis differs in appearance in different species of the Sciuridae family (Fig. 5). All combinations can, however, be allocated to four basic types:

Type I - all three ducts: ductus deferens, ductus excretorius and ductus prostaticus join at their distal ends and open in a common orifice (Sciurus vulgaris, S. carolinensis, C. suslicus, Ratufa indica, Tamias striatus).

Type II - ductus deferens and ductus excretorius join and open in a common orifice, while ductus prostaticus open separately (Marmota marmota, C. citellus, Tamiasciurus hudsonicus).

Type III - ductus deferens open separately, and ductus excretorius and ductus prostaticus join and open in a common orifice (Funambulus palmarum).

Type IV - all the ducts open with separate orifices (C. tridecemlineatus).

The topographical arrangements described of the ducts and their openings in different species do not constitute a constant character, since there is a certain degree of variability here. In C. suslicus the arrangement of the ducts may sometimes differ from those usually found. Attention was drawn to this by Mossman et al. (1932) in describing the course they take in Tamias striatus. He considers that this is due to the very small distances separating the ducts, hence the different ways of connection may occur.

The anatomical terms "glandula bulbi « and "ductus penis « were suggested by Mossman et al. (1932) for the glandular dilation of the ducts of gl. bulbourethrales (Cowperi) in bulbus penis and for the duct running from this dilation into the penis.

$\mathrm{Kratochvil}$ (1964) does not include the publications of American authors in the literature to which he refers and gives a different name for the gland in bulbus penis, namely "glandulae bulbo-urethrales accessoriae «, and for the duct of this gland running into the penis — „ductus glandularium bulbo-urethralium communis», which is connected with

bp - bulbus penis, ccp - corpus cavernosum penis, cp - crura penis, csp - corpus spongiosum penis, dgbu - ductus glandulae bulbourethralis, dpn - ductus penis, gbpi - glandula bulbi pars intermedia, gbpl - glandula bulbi pars lateralis, gbu - glandula bulbo-urethralis, gp - glans penis, oue - orificium urethrae externum, pmu - pars membranacea urethrae, psu - pars spongiosa urethrae, ssb - septum sagittale bulbi, $\mathrm{x}$ - juncture of ductus penis with canalis urogenitalis, $1-S$. vulgaris (drawing based on description: $\mathrm{K} \mathrm{r}$ ölli $\mathrm{ng}, 1921$ ), $2-\mathrm{S}$. carolinensis, $3-S$. niger, $4-C$. tridecemlineatus (M o s s m a n et al., 1932), $5-C$. suslicus and C. citellus (orig.), 6 - Marmota marmota latirostris (drawing based on description: Kratochvil, 1964), 7 - Tamias striatus (Mos sman et al., 1932), 8 - Ratufa indica maxima (Pras a d, 1954). 
the term ductus Cowperi communis used by $\mathrm{Kr}$ ölling (1921). The nomenclature suggested by Mossma n et al. (1932) has been used for the present study.

Glandula bulbi consists mainly of two large chambers separated from each other by a thin septum sagittale and lined by folded columnar epithelium. A two-chamber gland of this kind is found in C. suslicus, C. citellus, Marmota marmota, Tamias striatus and Ratufa indica. In other species $g l$. bulbi has a third, smaller chamber (pars intermedia) lying in the middle part near the dorsal wall of the gland (Fig. 6). This part also is lined by columnar epithelium. A gland of similar structure occurs in Sciurus vulgaris, $S$. carolinensis, $C$. tridecemlineatus. In the last of these this gland is very large, and is $20 \mathrm{~mm}$ wide. The epithelium lining the folds of glandula bulbi differs fundamentally from the epithelium in Cowper's glands. It is folded, its cells are larger and contain granular cytoplasm. This was clearly visible in C. suslicus and C. citellus, and Mos s m a n et al. (1932) also drew attention to it.

Ductus penis opens into canalis urogenitalis usually before flexura penis, at differing distances from it. In $C$. suslicus and $C$. citellus the juncture of these two ducts is situated about $1.5 \mathrm{~mm}$ and in C. tridecemlineatus about $8 \mathrm{~mm}$ from flexura penis. In other species (Marmota marmota, Tamias striatus) ductus penis opens immediately before glans penis.

According to Mossman et al. (1932) and Prasad (1954) gl. bulbi and ductus penis do not occur in such species of the Sciuridae family as Tamiasciurus hudsonicus and Funambulus palmarum. In T. hudsonicus, on the other hand, there is a non-glandular ventrally situated sinus urethrae bulbi (diverticulum urethrae). These facts play an important role in establishing the relationship of these species to other representatives of the Sciuridae family.

\section{REFERENCES}

1. Conaway C., 1958: The uterus masculinus of Castor canadensis. J. Manm., 39, 1: $97-108$.

2. Kratochvil J., 1964: Das männliche Genitalsystem des europäischen Bergmurmeltiere Marmota marmota latirostris K rat., 1961. Z. Säugetierkde, 2!, 5: $290-304$.

3. Krölling O., 1921: Die akzessorischen Geschlechtsdrüsen und Männlichen Kopulationsorgane von Sciurus vulgaris. Z. anat. Entwicklungsgesch., 61, 5/6: $402-438$.

4. Layne J. N., 1954: The os clitoridis of some american Sciuridae. J. Manm., $35,3: 357-366$.

5. Me is e n heimer J., 1930: Geschlecht und Geschlechter in Tierreiche. Gustav Fischer Verlag: $1-500$. Jena. 
6. Mossman H. W., Lawlah J. W. \& Bradley J. A., 1932: The male reproductive tract of the Sciuridae. Amer. J. Anat., 51: 89-157.

7. Nomina Anatomica Veterinaria. 1968. Vienna: 1-144.

8. Ottow B., 1955: Biologische Anatomie der Genitalorgane und der Fortpflanzung der Säugetiere. Gustav Fischer Verlag: 1-201. Jena.

9. Pfeiffer E. W., 1956: The male reproductive tract of primitive rodent, Aplodontia rufa. Anat. Rec., 124, 4: 629-637.

10. $\mathrm{Pr}$ a s a d M. R. N., 1954: The male genital tract of two genera of indian squirrels. J. Mamm., 35, 4: 471-485.

11. Rešetnik E. G., B a la hn in I. O., 1967: Pro dejaki vidmini troh vidiv hovrahiv rodu Citellus fauni URSR. Dopovidi AN URSR, B 5: 465-468.

Accepted, June 5, 1971.

Department of Comparative Anatomy of Vertebrates,

Maria Curie-Skłodowska University,

Lublin, Akademicka 19.

\section{Stefan MĘCZYNSSKI}

\section{ANALIZA MORFOHISTOLOGICZNA UKŁADU ROZRODCZEGO MESKIEGO SUSEOW}

\section{Streszczenie}

Opisano budowę układu rozrodezego męskiego Citellus suslicus (G ueldensta edt, 1770) i Citellus citellus (L innae us, 1766) u dorosłych osobników, będących w okresie rui.

Stwierdzono obecność gl. bulbi i ductus penis. U obydwóch badanych gatunków gruczol ten jest dwukomorowy i nie posiada części pośredniej (pars intermedia) (Fot. 5, Fig. 6). Ductus penis lączy się z canalis urogenitalis przed zgięciem brzusznym penis (flexura penis).

Prostata jest gruczołem pojedynczym, w którym wyodrębniają się dwie części: wydzielnicza i zbiornikowa (Fig. 3).

Występują parzyste gl. vesiculares i gl. bulbo-urethrales z charakterystycznie zwiniętymi przewodami wyprowadzającymi (Fot. 1).

Swiatio pars pelvina urethrae podzielone jest na komory przez 13-14 par przegród (septa urethrae) (Fig. 1). Nie stwierdzono obecności gl. urethrales.

Wykazano różnice w przebiegu końcowych odcinków przewodów wyprowadzających gruczołów płciowych w colliculus seminalis i sposobie ich ujścia do canalis urogenitalis. U C. suslicus - ductus deferens, ductus excretorius i ductus prostaticus lączą się i uchodzą wspólnym otworem (ostium ejaculatorium) (Fot. 3c, Fig. 5). U C. citellus - ductus deferens i ductus excretorius uchodzą wspólnym otworem, natomiast ductus prostaticus uchodzi osobnym otworem (Fot. 10b, Fig. 5). Uterus masculinus stwierdzono jedynie u C. suslicus (Fot. 4).

Występują różnice w budowie os glandis (Fig. 4). U C. citellus jest ona większa i posiada charakterystyczny wyrostek, który znajduje się przed jej rozszerzoną iopatkowato częścią przednią.

Nie stwierdzono obecności gl, praeputiales.

Uzyskane wyniki porównano z analogicznymi danymi dla innych przedstawicieli rodziny Sciuridae. 


\section{EXPLANATION OF PLATES}

Table I

Photo 1. Genital organs of C. suslicus - view from lateral side.

Photo 2. Cross-section through collum vesicae urinariae in C. suslicus.

Photo 3. Cross-section through colliculus seminalis in C. suslicus.

a - juncture of ductus deferens with ductus excretorius, b - juncture of ductus deferens and ductus excretorius with ductus prostaticus, c - opening of ductus ejaculatorius.

\section{Table II}

Photo 4. Cross-section through part of uterus masculinus in C. suslicus.

Photo 5. Cross-section through glandula bulbi in C. suslicus.

Photo 6. Cross-section through ductus penis and canalis urogenitalis in C. suslicus. Photo 7. Cross-section through ductus penis and canalis urogenitalis in C. suslicus. View showing juncture of the two ducts.

Photo 8. Cross-section through glans penis in C. suslicus.

\section{Table III}

Photo 9. Cross-section through collum vesicae urinariae in C. citellus.

Photo 10. Cross-section through colliculus seminalis in C. citellus.

$\mathrm{a}-$ juncture of ductus deferens with ductus excretorius, b - independent opening - $\quad$ of ductus prostaticus.

Photo 11. Cross-section through part of gl. vesicularis. Photo 12. Cross-section through part of prostata.

\section{ABBREviations}

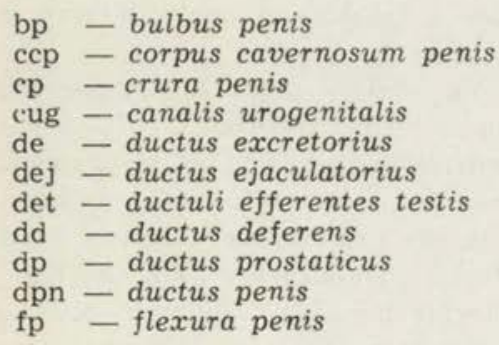

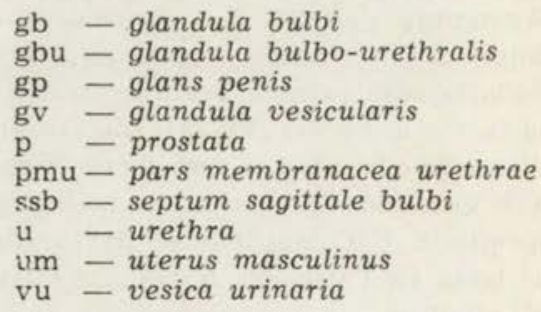



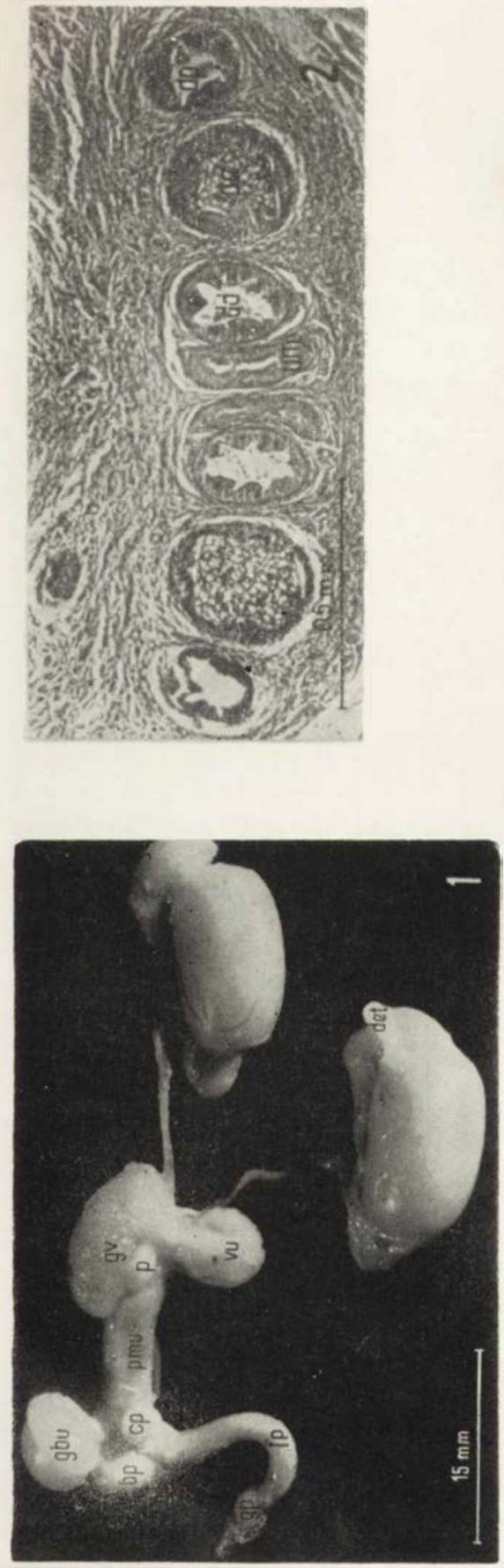

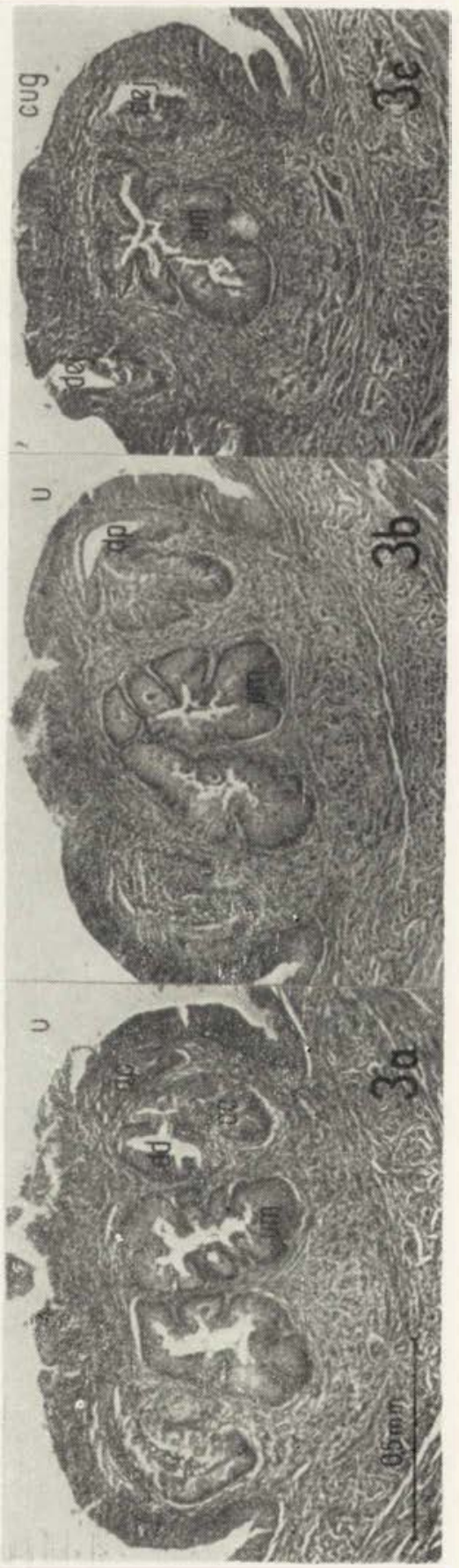



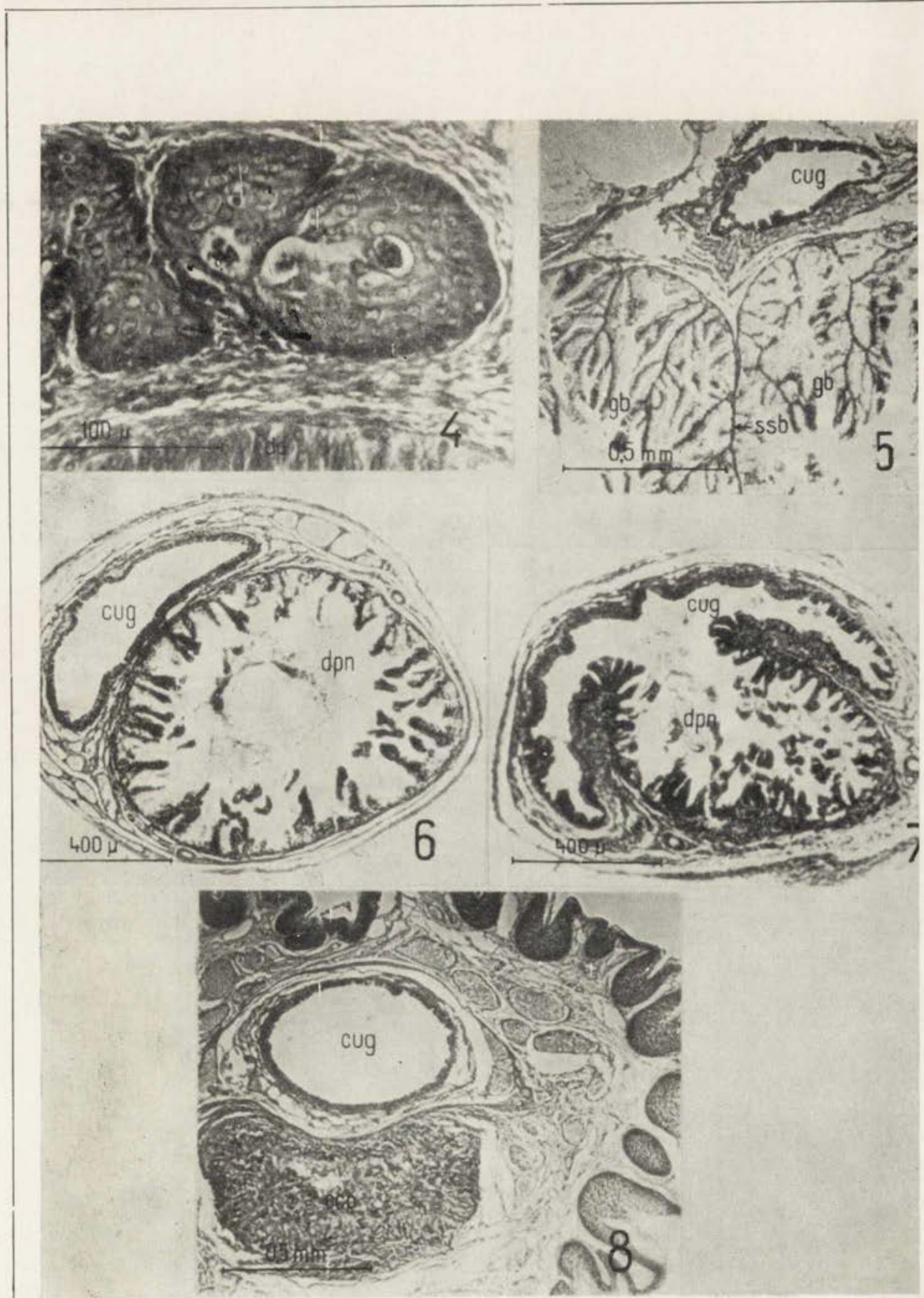


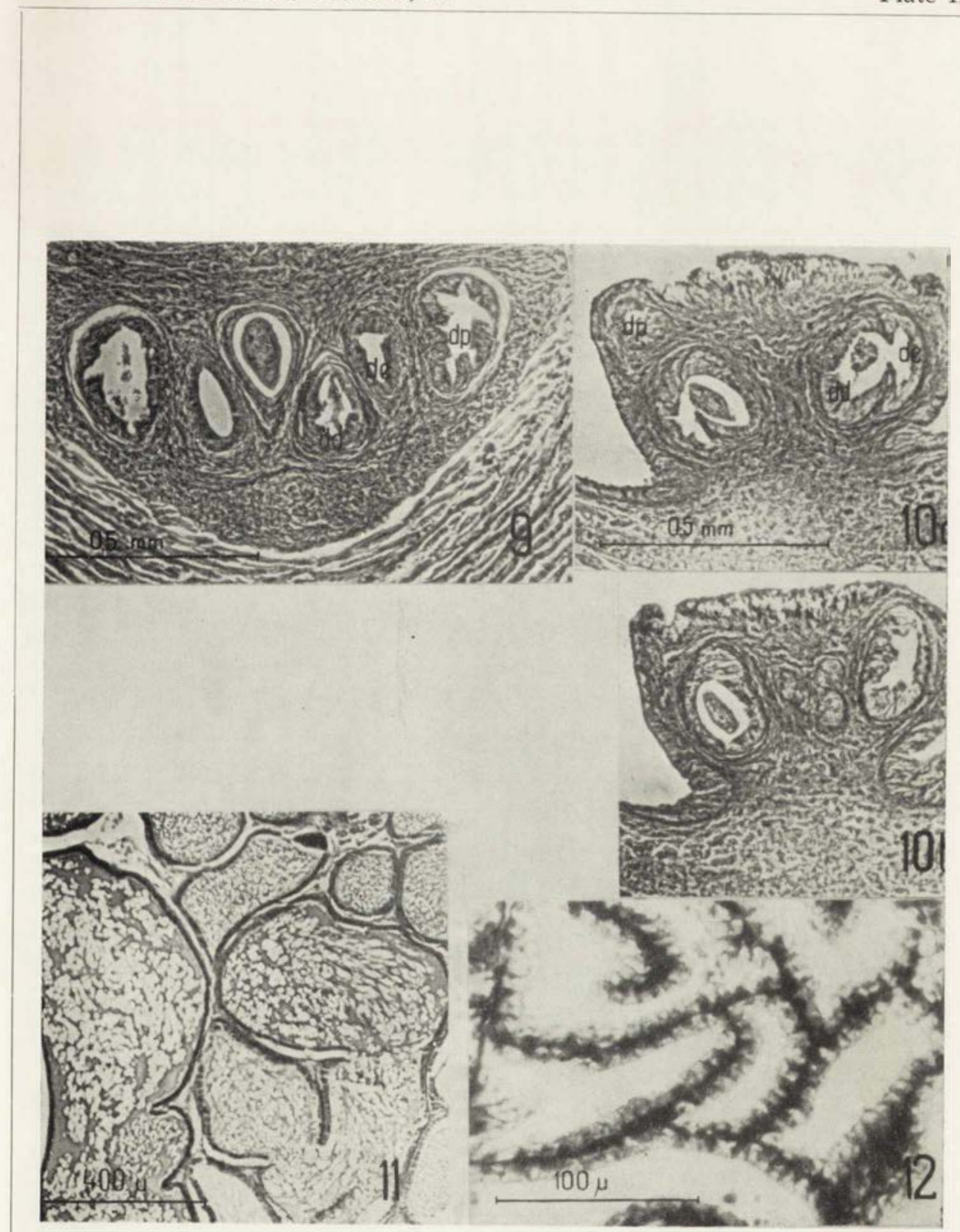

